\title{
Association between Fever during Admission and Outcome of Treatment in Tuberculous Meningitis Patients in Hasan Sadikin General Hospital Bandung
}

\author{
Regita A. Kuswanto*, Ahmad Rizal ${ }^{* *}$, R.Raspati C.Koesoemadinata*** \\ *Faculty of Medicine Padjadjaran University \\ **Department of Neurology Faculty of Medicine Padjadjaran University \\ ***Department of Biomedical Sciences Faculty of Medicine Padjadjaran University \\ Jl. Prof. Eyckman No. 38 Bandung 40161 Indonesia \\ Email : kregitaardhia@ymail.com
}

\begin{abstract}
Tuberculous meningitis (TBM) is the most common type of meningitis with a high mortality rate $(20-41 \%)$. There are limited data on factors associated with outcome of treatment, especially in Indonesia. Fever is a common inflammatory process in meningitis patients. This study aims to investigate the association between fever during admission and outcome of treatment in TBM patients treated in the In-patient Neurology Department at Hasan Sadikin Hospital Bandung. This is an observational retrospective cohort study conducted by using medical records from 2017. The inclusion criteria of this study were all medical records of inpatients who were diagnosed as TBM and $\geq 18$ years old, while the exclusion criteria were incomplete medical records. The variables in this study were age, gender, body temperature, classification of TBM, and Glasglow Outcome Scale (GOS). There were 125 medical records which fulfilled the inclusion criteria. Kruskal- Wallis test showed that fever was not significantly associated with GOS ( $p=0.193)$. In conclusion, fever during admission was not associated with GOS in TBM patients.
\end{abstract}

Keywords: tuberculous meningitis, fever, Glasglow Outcome Scale, outcome 


\title{
Hubungan Panas Badan Saat Masuk Rumah Sakit dengan Luaran Terapi pada Pasien Meningitis Tuberkulosis yang Dirawat di RSUP Hasan Sadikin Bandung
}

\author{
Regita A Kuswanto*, Ahmad Rizal**, R.Raspati C.Koesoemadinata**** \\ *Fakultas Kedokteran Universitas Padjadjaran \\ **Departemen Neurologi Fakultas Kedokteran Universitas Padjadjaran \\ ***Departemen Biomedik Fakultas Kedokteran Universitas Padjadjaran \\ Jl. Prof. Eyckman No. 38 Bandung 40161 Indonesia \\ Email : kregitaardhia@ymail.com
}

\begin{abstract}
Abstrak
Meningitis tuberkulosis (MTB) adalah tipe meningitis yang paling sering ditemukan dan memiliki tingkat mortalitas tinggi (20-41\%). Data mengenai faktor-faktor yang berkaitan dengan luaran terapi pada pasien meningitis masih terbatas, khususnya di Indonesia. Meningitis tuberkulosis (MTB) adalah tipe inflamasi umum yang ditandai dengan terjadinya demam. Penelitian ini bertujuan untuk mencari hubungan antara demam saat masuk rumah sakit dengan luaran terapi pasien MTB di Instalasi Rawat Inap Penyakit Saraf RSUP Hasan Sadikin. Penelitian ini merupakan penelitian observasional kohort retrospektif menggunakan data rekam medis pada tahun 2017. Kriteria inklusi dari penelitian ini adalah seluruh rekam medis pasien yang telah terdiagnosis MTB dan berusia $\geq 18$ tahun, dan kriteria eksklusinya adalah data rekam medis pasien yang tidak lengkap. Variabel yang diteliti adalah usia, jenis kelamin, suhu tubuh, klasifikasi MTB, dan luaran GOS (Glasgow Outcome Scale). Sampel yang digunakan dalam penelitian ini sebanyak 125 sampel. Panas badan diuji secara statistik dengan menggunakan uji statistik Kruskal-Wallis dan didapatkan hasil tidak signifikan mempengaruhi GOS $(p=0,193)$. Penelitian ini menyimpulkan tidak terdapat hubungan antara panas badan saat masuk rumah sakit dengan GOS saat akhir terapi pada pasien MTB.
\end{abstract}

Kata kunci: meningitis tuberkulosis, panas badan, demam, GOS, luaran 


\section{Pendahuluan}

Tuberkulosis (TB) adalah penyakit infeksi yang disebabkan oleh bakteri Mycobacterium tuberculosis (Mtb). Penyakit TB terutama menyerang paru-paru, namun juga dapat menyerang organ lain yang disebut dengan TB ekstra paru. Meningitis tuberkulosis (MTB) adalah TB ekstra paru yang mengenai selaput pembungkus otak serta sumsum tulang belakang dan menyebabkan proses peradangan. ${ }^{1}$ Meningitis tuberkulosis merupakan TB pada susunan saraf pusat (SSP) yang paling sering dan paling berat dengan tingkat kematian yang tinggi. ${ }^{2}$ Penderita MTB tercatat sebanyak 1,5\% ditemukan pada pasien-pasien TB. ${ }^{1}$ Tingkat mortalitas dari MTB tergolong tinggi dengan persentase 20-41\%. ${ }^{2}$ Beberapa faktor yang diketahui berhubungan dengan risiko kematian yang tinggi adalah Human Immunodeficiency Virus (HIV) (40-58\%) $)^{3,4}$, tingkat keparahan penyakit, level kesadaran pasien, serta usia. Human Immunodeficiency Virus merupakan virus yang menyerang kekebalan tubuh dan melemahkan sistem kemampuan tubuh untuk melawan infeksi dan penyakit. Meningitis tuberkulosis adalah salah satu dari lima penyakit TB ekstra paru yang paling sering terjadi dengan persentase $0.7 \%$ dari seluruh kasus TB Tingkat keparahan MTB digolongkan berdasarkan British Medical Research Council grade (BMRC) menjadi tiga tingkatan yaitu tingkat 1,2 , dan $3 .^{5}$

Meningitis adalah proses inflamasi pada selaput meningen, pada kondisi ini demam merupakan salah satu gejala yang sering ditemukan. Inflamasi pada rongga kepala berbeda jika dibandingkan dengan proses peradangan di tempat lain. Peradangan pada rongga kepala dapat menyebabkan peningkatkan tekanan di rongga kepala. Rongga kepala sendiri memiliki ruang yang sempit, sehingga apabila terjadi peningkatan tekanan pada rongga kepala karena proses peradangan maka akan berpengaruh terhadap luaran pada pasien. Luaran merupakan kondisi pasien saat tindak lanjut terakhir sebelum keluar dari rumah sakit. ${ }^{5}$ Hasil luaran dapat dinyatakan dengan menggunakan Glasgow Outcome Scale (GOS). Penilaian GOS terdiri atas lima bentuk luaran yaitu meninggal, keadaan vegetatif, cacat berat, cacat ringan hingga sedang, dan pemulihan baik.

Sampai saat ini belum pernah diselidiki hubungan antara panas badan saat masuk yang merupakan tanda inflamasi umum dengan luaran GOS. Oleh karena itu, peneliti bermaksud melakukan studi analisis mengenai hubungan antara panas badan dengan luaran setelah dirawat di rumah sakit pada pasien MTB yang di rawat di RSUP Dr. Hasan Sadikin Bandung. Tujuan dari penelitian ini adalah untuk mengetahui apakah gejala demam pada saat masuk rumah sakit dapat menjadi prediktor luaran terapi pasien MTB yang dirawat di RSUP 
Hasan Sadikin Bandung sehingga jika memang terdapat hubungan antara keduanya, maka penelitian ini dapat membantu dalam memprediksi luaran terapi pada pasien MTB.

\section{Metode}

Penelitian ini menggunakan pendekatan observasional dengan disain kohort retrospektif. Pengambilan data dilakukan dari Agustus hingga Oktober 2018 di Departemen Ilmu Penyakit Saraf. Data yang digunakan adalah data sekunder dari Instalasi Rekam Medis RSUP Dr. Hasan Sadikin Bandung. Subjek penelitian adalah semua pasien MTB yang datang ke rumah sakit dengan panas badan yang dirawat di Instalasi Rawat Inap Penyakit Saraf RSUP Hasan Sadikin Bandung dari bulan Januari sampai dengan Desember 2017. Metode pengambilan sampel yaitu whole sample. Kriteria inklusi dari penelitian ini yaitu seluruh pasien MTB yang berusia $\geq 18$ tahun dan kriteria eksklusi berupa data rekam medis pasien yang tidak lengkap.

Variabel yang dipakai pada penelitian adalah usia, jenis kelamin, suhu tubuh, GOS, serta klasifikasi MTB. Penilaian GOS adalah suatu sistem skoring/skala yang digunakan untuk menilai luaran atau proses pemulihan pasien-pasien yang mengalami kerusakan otak. GOS terdiri atas 5 tingkatan yaitu GOS 1 meninggal, GOS 2 pasien dalam keadaan vegetatif, GOS 3 cacat berat, GOS 4 cacat ringan hingga sedang, dan GOS 5 pemulihan baik. ${ }^{67,8}$ GOS dalam penelitian ini diklasifikasikan ke dalam 3 kategori yaitu luaran buruk (GOS 1), sedang (GOS 2, 3), dan baik (GOS 4, 5) untuk menyederhanakan analisis. Selain itu untuk klasifikasi MTB dilakukan berdasarkan kriteria British Medical Research Council ${ }^{9,10}$ terdiri dari MTB tingkat 1 Glasglow Coma Scale (GCS) 15 tanpa fokus defisit neurologis), MTB tingkat 2 (GCS 11-14 dengan/tanpa fokus defisit neurologis atau GCS 15 dengan fokus defisit neurologis), dan MTB tingkat 3 (GCS $<11$ dengan/tanpa fokus defisit neurologis). ${ }^{11}$

Karakteristik pasien dipresentasikan dalam bentuk proporsi (\%), median, dan interquartile range. Hubungan antara suhu tubuh dengan kategori GOS pada studi ini dianalisis dengan menggunakan uji Kruskal-Wallis dan Chi-square. Studi ini telah mendapat persetujuan etik nomor 373/UN6.KEP/EC/2018 yang dikeluarkan oleh Komite Etik Penelitian Kesehatan Fakultas Kedokteran Universitas Padjadjaran serta mendapat surat izin penelitian yang dikeluarkan oleh RSUP Dr. Hasan Sadikin Bandung, nomor: LB.02.01/X.2.2.1/13351/2018. 


\section{Research Article}

\section{Hasil}

Total pasien yang terdiagnosis MTB dari bulan Januari sampai dengan Desember 2017 tercatat sebanyak 152 orang (Gambar 1). Sebanyak 15 data dieksklusi karena tidak ditemukannya rekam medis pasien, sehingga hanya tersisa sebanyak 137 pasien dengan catatan rekam medis. Selanjutnya 12 pasien dieksklusi dari studi dikarenakan pasien berusia $<18$ tahun. Sisanya terdapat sebanyak 125 pasien MTB yang akan dianalisis.

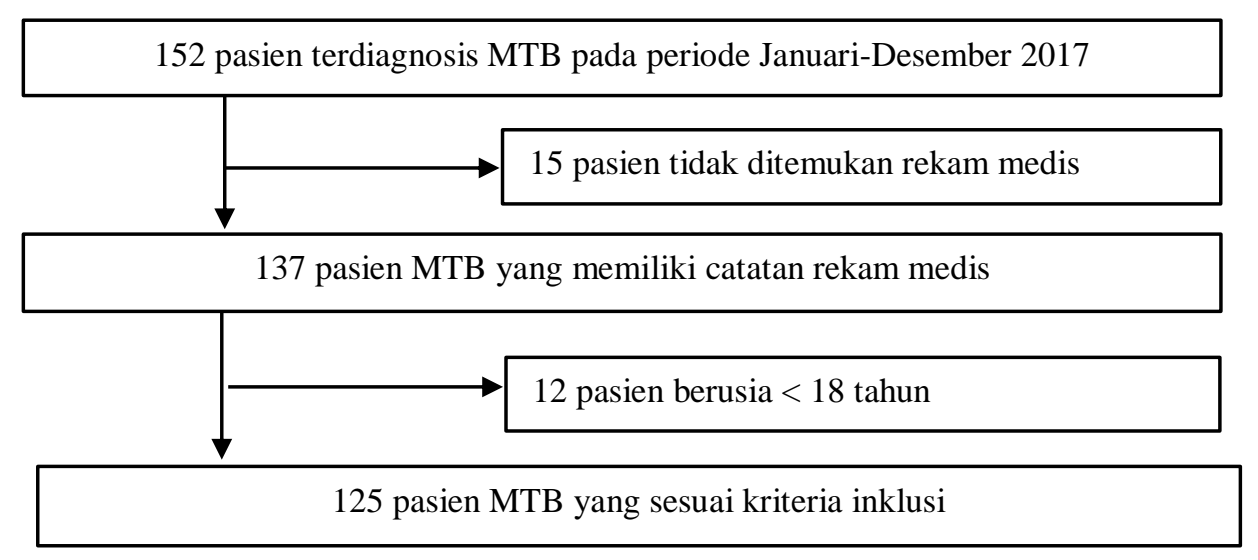

Gambar 1 Alur Inklusi Subjek Penelitian

Karakteristik pasien MTB yang masuk ke rawat inap di RSUP Dr. Hasan Sadikin Bandung digambarkan pada tabel 1. Mayoritas pasien berjenis kelamin laki-laki, yaitu sebanyak 76 pasien $(60,8 \%)$, dengan median usia pasien 30 tahun serta klasifikasi MTB tingkat 2 memiliki persentase terbesar yaitu $71,2 \%$. Kriteria klinis yang paling sering ditemukan pada pasien adalah terjadinya penurunan kesadaran yang terjadi pada 88 pasien $(70,4 \%)$, dengan kriteria CSS mayoritas jernih (52\%), serta median jumlah sel yaitu 101. Selain itu untuk persentase leukosit, PMN memiliki median 33 sedangkan MN yaitu 67, dengan nilai minimal 0 dan maksimal 100. Median untuk konsentrasi protein 185,5 dan glukosa CSS adalah 25. Gambaran CT scan terbanyak adalah terjadinya peningkatan basal meningeal pada 34 pasien (27,2\%), serta ditemukannya bukti TB di tempat lain dari hasil pemeriksaan X-ray terbanyak adalah sugestif adanya TB positif pada 53 pasien $(42,4 \%)$. 
Tabel 1 Distribusi Karakteristik Pasien MTB

\begin{tabular}{|c|c|c|}
\hline Karakteristik & Jumlah (n) & $\%$ \\
\hline Usia (tahun), median (range) & 30 & $23-41$ \\
\hline \multicolumn{3}{|l|}{ Jenis kelamin } \\
\hline Laki-laki & 76 & 60,8 \\
\hline Perempuan & 49 & 39,2 \\
\hline \multicolumn{3}{|l|}{ Klasifikasi MTB } \\
\hline Tingkat 1 & 6 & 4,8 \\
\hline Tingkat 2 & 89 & 71,2 \\
\hline Tingkat 3 & 30 & 24,0 \\
\hline \multicolumn{3}{|l|}{ Kriteria klinis } \\
\hline Durasi gejala lebih dari 5 hari & 85 & 68,0 \\
\hline Gejala sistemik dari TB & 51 & 40,8 \\
\hline $\begin{array}{l}\text { Riwayat TB / kontak } \\
\text { dengan penderita TB }\end{array}$ & 44 & 35,2 \\
\hline Fokus defisit neurologis & 24 & 19,2 \\
\hline Cranial nerve palsy & 8 & 6,4 \\
\hline Penurunan kesadaran & 88 & 70,4 \\
\hline \multicolumn{3}{|l|}{ Kriteria CSS } \\
\hline Jernih & 65 & 52,0 \\
\hline Jumlah sel* (median, range) & 101 & $1-2508$ \\
\hline \multicolumn{3}{|l|}{ Persentase Leukosit } \\
\hline PMN (median, renge) & 33 & $0-100$ \\
\hline MN (median, range) & 67 & $0-100$ \\
\hline Konsentrasi protein* (median, range) & 185,5 & $33-5210$ \\
\hline Glukosa CSS* (median, range) & 25 & $2-159$ \\
\hline \multicolumn{3}{|l|}{ Gambaran CT scan } \\
\hline Hydrocephalus & 12 & 9,6 \\
\hline Tuberculoma & 2 & 1,6 \\
\hline Infarctus & 4 & 3,2 \\
\hline Peningkatan basal meningeal & 34 & 27,2 \\
\hline Precontrast basal hyperdensity & 0 & 0 \\
\hline \multicolumn{3}{|l|}{ Bukti TB di tempat lain } \\
\hline Chest $\mathrm{X}$ ray sugestif adanya TB & 53 & 42,4 \\
\hline \multicolumn{3}{|l|}{ Positif } \\
\hline Miliary TB & 18 & 14,4 \\
\hline BTA positif* & 4 & 3,2 \\
\hline $\begin{array}{l}\text { Keterangan: } \\
\text { Semua data ditampilkan dalam bentuk n (\%), kecua } \\
\text { IQR, interquartile range; MTB, meningitis tuberkul } \\
\text { CSS, cairan serebrospinal; PMN, polymorphonucle } \\
\text { BTA, basil tahan asam } \\
\text { *Data tersedia } 100 \% \text { untuk semua variabel, kecuali } \\
\text { konsentrasi protein sebanyak } 84 \text { sampel }(67,2 \%) \text {, k } \\
\text { data BTA sebanyak } 22(17,6 \%) \text {. }\end{array}$ & $\begin{array}{l}\text { kan tersendiri; } \\
\text { kulosis; } \\
\text { uclear } \\
\text { el dalam CSS seb } \\
\text { osa sebanyak } 86\end{array}$ & pel $(69,6 \%)$, \\
\hline
\end{tabular}

Pada tabel 3, suhu tubuh dengan luaran GOS buruk memiliki median suhu 37,85. Median suhu ini lebih tinggi jika dibandingkan dengan median suhu pada luaran GOS sedang $(37,45)$ dan baik $(37,10)$, namun setelah dilakukan uji Kruskal-Wallis, tidak ditemukan adanya hubungan yang signifikan secara statistik $(\mathrm{p}=0,193)$. Data suhu tubuh selanjutnya dianalisis dengan cara berbeda, digolongkan menjadi dua kategori yaitu panas $\left(\geq 37,8^{\circ} \mathrm{C}\right)$ dan tidak panas $\left(<37,8^{\circ} \mathrm{C}\right)$ dan dilakukan tes Chi square tetap menunjukkan hasil tidak bermakna ( $\left.\mathrm{p}=0.264\right)$. 
Tabel 2 Hubungan Karakteristik Pasien MTB dengan Luaran

\begin{tabular}{|c|c|c|c|c|}
\hline \multirow[b]{2}{*}{ Karakteristik } & \multicolumn{3}{|c|}{ Kategori Luaran Pasien } & \multirow{2}{*}{$\begin{array}{c}\text { Nilai } \\
\text { p* }^{*}\end{array}$} \\
\hline & $\begin{array}{l}\text { GOS buruk } \\
\qquad(n=40)\end{array}$ & $\begin{array}{l}\text { GOS sedang } \\
\quad(n=18)\end{array}$ & $\begin{array}{c}\text { GOS baik } \\
(n=67)\end{array}$ & \\
\hline Usia (tahun), median (range) & $\begin{array}{r}34,5 \\
(18-76)\end{array}$ & $\begin{array}{r}32,5 \\
(20-56)\end{array}$ & $\begin{array}{r}26 \\
(18-69)\end{array}$ & 0,115 \\
\hline \multicolumn{5}{|l|}{ Jenis kelamin } \\
\hline $\begin{array}{l}\text { Laki-laki } \\
\text { Perempuan }\end{array}$ & $\begin{array}{l}25(32,9) \\
15(30,6)\end{array}$ & $\begin{array}{r}13(17,1) \\
5(10,2)\end{array}$ & $\begin{array}{l}38(50,0) \\
29(59,2)\end{array}$ & 0,472 \\
\hline \multicolumn{5}{|l|}{ Klasifikasi MTB } \\
\hline Tingkat 1 & 0 & 0 & $6(100)$ & \multirow[b]{2}{*}{0,001} \\
\hline $\begin{array}{l}\text { Tingkat } 2 \\
\text { Tingkat } 3\end{array}$ & $\begin{array}{l}25(28,1) \\
15(50,0)\end{array}$ & $\begin{array}{r}11(12,4) \\
7(23,3)\end{array}$ & $\begin{array}{r}53(59,6) \\
8(26,7)\end{array}$ & \\
\hline \multicolumn{5}{|l|}{ Bukti TB di tempat lain } \\
\hline $\begin{array}{l}\text { Chest } X \text { ray sugestif adanya } \\
\text { TB Positif }\end{array}$ & $18(34,0)$ & $7(13,2)$ & $28(52,8)$ & 0,900 \\
\hline TB Milier & $6(31,6)$ & $2(10,5)$ & $10(57,9)$ & 0,856 \\
\hline BTA positif & $3(75,0)$ & $0(0)$ & $1(25,0)$ & 0,125 \\
\hline $\begin{array}{l}\text { Keterangan: } \\
\text { Semua data ditampilkan dalam bentuk } \\
\text { IQR, interquartile range; MTB, menin } \\
\text { BTA, basil tahan asam } \\
\text { *Usia dianalisis dengan menggunakan } \\
\text { Jenis kelamin, chest X-ray sugestif ada } \\
\text { Klasifikasi MTB, BTA dianalisis deng }\end{array}$ & $\begin{array}{l}\text { kecuali yang din } \\
\text { uberkulosis; TB, } \\
\text { uskal-Wallis } \\
\text { B positif, dan TB } \\
\text { Mann-Whitney }\end{array}$ & $\begin{array}{l}\text { atakan tersendiri; } \\
\text { berkulosis; }\end{array}$ & $x^{2}=$ & \\
\hline
\end{tabular}

Tabel 3 Hubungan Panas Badan Pasien MTB Dengan Luaran

\begin{tabular}{|c|c|c|c|c|}
\hline \multirow[b]{2}{*}{ Karakteristik } & \multicolumn{3}{|c|}{ Kategori Luaran Pasien } & \multirow[b]{2}{*}{ Nilai p* } \\
\hline & $\begin{array}{c}\text { GOS } \\
\text { buruk } \\
(n=40)\end{array}$ & $\begin{array}{c}\text { GOS sedang } \\
\quad(n=18)\end{array}$ & $\begin{array}{c}\text { GOS baik } \\
(n=67)\end{array}$ & \\
\hline Suhu tubuh $\left({ }^{\circ} \mathrm{C}\right)$, median $(\text { range })^{*}$ & $\begin{array}{r}37,85 \\
(36-40,5)\end{array}$ & $\begin{array}{r}37,45 \\
(36-39,1)\end{array}$ & $\begin{array}{r}37,1 \\
(36-39,6)\end{array}$ & 0,193 \\
\hline \multicolumn{5}{|l|}{ Panas badan $\left(\geq 37.8^{\circ} \mathrm{C}\right)^{*}$} \\
\hline $\begin{array}{l}\text { Ya } \\
\text { Tidak }\end{array}$ & $\begin{array}{l}20(50) \\
20(50)\end{array}$ & $\begin{array}{r}8(44,44) \\
10(55,56)\end{array}$ & $\begin{array}{l}23(34,33) \\
44(65,67)\end{array}$ & 0,264 \\
\hline
\end{tabular}

\section{Diskusi}

Panas badan saat pasien masuk ke rumah sakit tidak dapat menjadi prediktor luaran pasien MTB. Jika dilihat dari perjalanan penyakitnya, panas badan dapat memiliki pengaruh terhadap luaran GOS. ${ }^{12}$ Mycobacterium tuberculosis pertama akan menginfeksi paru-paru dan bermultiplikasi pada makrofag alveolar. Multiplikasi makrofag alveolar menyebabkan penyebaran $M t b$ ke organ lain, salah satunya otak khususnya pada bagian selaput pembungkus otak (meninges). 
Tubuh akan mengalami infeksi dan terjadi proses peradangan pada selaput pembungkus otak, hal ini menyebabkan tubuh menstimulasi monosit dan makrofag untuk memproduksi pirogen endogen seperti IL-1, IL-6, TNF- $\alpha$, dan IFN- $\gamma$. Sitokin pirogenik akan bekerja pada Preoptic Anterior Hypothalamus untuk menginduksi produksi Prostaglandin E2 dan terjadi peningkatan set point temperatur tubuh yang menyebabkan pasien demam. Prostaglandin E2 juga meningkatkan Blood Brain Barrier Permeability yang akan menyebabkan edema vasogen dan mengakibatkan terjadi peningkatan tekanan intrakranial di otak.

Aliran darah ke otak menjadi berkurang dan akan mempengaruhi luaran pada pasien MTB. Panas badan pasien MTB tidak bermakna terhadap GOS karena jumlah sampel yang kurang besar jika dibandingkan dengan penelitian sebelumnya. ${ }^{5}$ Selain panas badan terdapat beberapa faktor lain yang dapat dijadikan prediktor luaran yaitu jenis kelamin, usia, klasifikasi MTB, level kesadaran pasien (Glasglow Outcome Scale), ${ }^{1}$ lama durasi penyakit, kelemahan fokal, defisit saraf kranial, dan hidrosefalus. ${ }^{5}$

Laki-laki yang menderita MTB memiliki proporsi lebih banyak pada populasi studi (60.8\%), penemuan ini mirip dengan studi yang dilakukan di negara Taiwan, yang melaporkan bahwa angka kejadian MTB lebih tinggi pada laki-laki $(65.7 \%){ }^{6}$ Selain itu, studi yang dilakukan di Thailand dan India juga melaporkan bahwa persentase lebih tinggi pada pasien MTB laki-laki. ${ }^{12}$ Akan tetapi, pada penelitian ini tidak ditemukan perbedaan GOS yang signifikan antara kelompok dengan jenis kelamin yang berbeda. Bila dibandingkan dengan penelitian yang dilakukan di Taiwan, mereka menggunakan case control sebagai disain penelitian dan dilakukan secara retrospektif selama periode 6 tahun, meskipun jumlah data hanya sebanyak 108 pasien. $^{6}$

Peneliti juga menemukan bahwa semakin tua usia maka akan berpengaruh terhadap luaran GOS yang lebih buruk pada penelitian sebelumnya ${ }^{7}$, tetapi hasil pada penelitian ini menunjukkan tidak adanya perbedaan yang signifikan antara usia dan luaran GOS pasien MTB. Penelitian sebelumnya ${ }^{7}$ menggunakan studi pengamatan secara prospektif dengan jumlah total pasien sebanyak 209 pasien. Tingkatan dalam MTB tergantung pada tanda-tanda neurologis dan level kesadaran pada saat datang ke rumah sakit. Studi sebelumnya menunjukkan adanya korelasi antara tingkat keparahan MTB dengan skor GOS yang lebih buruk pada saat pasien pulang dari rumah sakit., ${ }^{7}$ dan hal ini dikonfirmasi pada penelitian ini; klasifikasi MTB memiliki perbedaan yang signifikan dengan luaran GOS. Semakin berat tingkat keparahan MTB yang diderita pasien, maka akan semakin buruk luaran GOS. 


\section{Research Article}

Penelitian ini menggunakan data sekunder dari rekam medis pasien yang terdapat di Instalasi Rekam Medik RSUP Hasan Sadikin, sehingga terdapat beberapa keterbatasan penelitian. Keterbatasan tersebut adalah tidak ditemukan data rekam medis setiap pasien serta data tidak lengkap sehingga jumlah sampel penelitian tidak cukup untuk mewakili populasi. Waktu pengukuran suhu tubuh, serta riwayat pasien dalam mengkonsumsi obat penurun panas juga tidak jelas tercatat dalam rekam medis dan hal ini mungkin memengaruhi hasil analisis data dalam penelitian ini.

\section{Simpulan}

Pada penelitian ini tidak didapatkan adanya hubungan yang bermakna antara panas badan dengan GOS pada akhir terapi. Terdapat juga faktor-faktor lain yang berhubungan dengan luaran terapi pasien TBM. Untuk penelitian selanjutnya disarankan agar dilakukan penelitian prospektif pada pasien TBM dengan mengikutsertakan semua faktor yang mungkin menjadi prediktor luaran sebagai variabel bebas untuk dianalisis.

\section{Daftar Pustaka}

1. Misra UK, Kalita J, Betai S, Bhoi SK. Outcome of tuberculous meningitis patients requiring mechanical ventilation. J Crit Care. 2015;30(6):1365-9.

2. Güneş A, Uluca Ü, Aktar F, Konca Ç, Şen V, Ece A, et al. Clinical, radiological and laboratory findings in 185 children with tuberculous meningitis at a single centre and relationship with the stage of the disease. Ital $\mathbf{J}$ Pediatr. 2015;41(1):75.

3. Merkler AE, Reynolds AS, Gialdini G, Morris NA, Murthy SB, Thakur K, et al. Journal of the Neurological Sciences Neurological complications after tuberculous meningitis in a multi-state cohort in the United States. J Neurol Sci. 2017;375:460-3.

4. WHO Global Tuberculosis Report. 2015;27-36.

5. Modi M, Sharma K, Prabhakar S, Goyal MK, Takkar A, Sharma N, et al. Clinical and radiological predictors of outcome in tubercular meningitis : A prospective study of 209 patients. Clin Neurol Neurosurg. 2017;161(8):2934.

6. Erdem H, Ozturk-Engin D, Tireli H, Kilicoglu G, Defres S, Gulsun S, et al. Hamsi scoring in the prediction of unfavorable outcomes from tuberculous meningitis: results of Haydarpasa-II study. J Neurol. 2015;262(4):890-8.

7. Hsu P, Yang C, Ye J, Huang P, Chiang P, Lee M. Prognostic Factors of Tuberculous Meningitis in Adults : A 6Year Retrospective Study at a Tertiary Hospital in. J Microbiol Immunol Infect. 2010;43(2):111-8.

8. Chen C, Chang Y, Sy H, Chen WL, Yen H. Risk assessment of the outcome for cerebral infarction in tuberculous meningitis. Rev.Neurol. 2014;170(8-9):512-9.

9. Torok ME. Tuberculous meningitis: Advances in diagnosis and treatment. Br Med Bull. 2015;113(1):117-31.

10. Miftode EG, Dorneanu OS, Leca DA, Juganariu G, Teodor A, Hurmuzache M, et al. Tuberculous meningitis in children and adults: A 10-year retrospective comparative analysis. PLoS One. 2015;10(7):1-10.

11. Maria L, Feliciano C, Mauad F, Passeri M, Candido R, et al. A predictive score followed by nucleic acid ampli fi cation for adult tuberculous meningitis diagnosis in Southern Brazil . J Neurol Sci. 2017;379:253-8.

12. McCance KL, Huether SE, Brashers VL, Rote NS. Pathophysiology The Biologic Basis for Disease in Adults adn Children seventh edition. Elsevier; 2014. 498-500 p. 